\title{
Functional Analysis for Rolling Leaf of Somaclonal Mutants in Rice (Oryza sativa L.)
}

\author{
Young-Hie Park ${ }^{1}$, Hyun-Suk Lee ${ }^{1}$, Gi-Hwan Yi ${ }^{2}$, Jae-Keun Sohn' ${ }^{1}$, Kyung-Min Kim ${ }^{\text {* }}$ \\ ${ }^{1}$ School of Plant Biosciences, Kyungpook National University, Daegu, Korea; ${ }^{2}$ Department of Functional Crop, National Institute of \\ Crop Science, RDA, Milyang, Korea. \\ Email: yhpark4026@hanmail.net, ghyi@rda.go.kr, \{ddr3031,jhsohn,kkm\}@knu.ac.kr
}

Received December $28^{\text {th }}, 2010$; revised February $11^{\text {th }}, 2010$; accepted February $18^{\text {th }}, 2011$.

\begin{abstract}
This study was carried out to facilitate the functional analysis of rice genes. Some 297 insertion plants (1.7\%) of the entire lines with the endogenous retrotransposon Tos 17 were produced. Phenotypes of these plants in the $S_{2}$ generation were observed in the field according to different leaf types. Rolling leaf mutants showed thinner sclerenchymatous cells, defective arrangement of vascular bundles, and well-formed bulliform cells as compared to the parental cultivar. Two new copies of Tos17 were detected in the rolling leaf type. In the new leaf type, the copy number and activation of Tos12, 15 did not appear as 'Ilpum'. Flanking sequence tag (FST) analysis of Tos17 in the rolling leaf mutant indicated that new copies of Tos 17 were transposed on chromosomes 11 and 12. Annotated homologues of the tagging genes on chromosome 11 were arabinoxylan rabinofuranohydrolase isoenzyme AXAH-I and II. The tagging gene in chromosome 12 was highly correlated with 6 kinds of genes including a transcript regulated factor and a rough sheath 2-like protein. This rolling leaf and flanking sequence data will stimulate the functional analysis of rice genes.
\end{abstract}

Keywords: Tissue Culture, Somaclonal Variation, Mutant, Opaque Endosperm, Tos Element

\section{Introduction}

Tissue culture of plants is an important means to propagate genetically identical individuals asexually and to produce transgenic plants. However, undesired genetic and cytogenetic modifications are frequently generating genetic variability, somaclonal variations, induced during tissue culture. These tissue culture-induced mutations were reported in many plant species and seemed to be ubiquitous in plants [1,2]. Although tissue cuture-induced mutations were studied extensively as a source for plant improvement, little is known about their molecular causes. Specifically, somatic variations are becoming the limelight of breeders since they improve both the individual and species of crops [3,4]. Rice is used in genome study model of monocotyledonous plant because of the size of its genome $(\sim 430 \mathrm{Mb})$ being relatively small. Also, an international project had already gathered the functional analysis of gene from DNA sequence [5]. There are various methods to analyze the function of the gene. One method used was a genome tilling array to a specific mutation group while handling chemical mutation materials such as $\mathrm{N}$-methyl-
$\mathrm{N}$-nitrosourea (MNU) and ethyl methanesulfonate (EMS) or radiation. This method involved inserting foreign DNA fragments with labeled T-DNA, and using transition factor that exist in plants such as $A c / D s$ and Tos derivatives which are a "Knock-out" or "Knock-down" of the gene or activation [6-8]. T-DNA or Ac/Ds gene trap sys- tems needed a lot of time and effort because it involved breeding large-scale mutation populations through the process of transformation to introduce a marked-gene on a rice genome. On the other hand, retrotransposon such as Tos can easily get a somaclonal variant through tissue culture without processing the mutagen. This method was widely used for the rice gene function analysis in Japan's NIAS (National Institute of Agrobiological Science, http://Tos.nias.affrc.go.jp), France's CIRAD (Centre de Coopération Internationale en Recherche Agronomique pour le Développement, http://urgi.versailles. inra. fr/OryzaTagline), and Korea's POSTECH (Pohang University of Science and Technology, http://www.postech. ac.kr/life/pfg) [1]. Meanwhile, there are about 1,000 retrotransposons with 32 classes in the rice genome that existed [6] and, LTR (long terminal repeats) retrotransposon with a minimum of 59 classed which composed 
$17 \%$ of the rice entire genome, but research about the evolution or introduced time is insufficient [3]. The reverse transcription modulator (RTs; Reverse Transcriptase) of Tos family with 20 classes caused somaclonal variation because it was activated at the tissue culture which were only found in the japonica variety 'Nipponbare' [9-18]. However, very little is known about the ecotype and copy number of the rice species or kind of Tos.

Hence, japonica variety, 'Ilpum' was bred domesticcally for rice gene function analysis. $S_{1}$ and $S_{2}$ progeny populations were bred from the cultured seed, and the incidence of variant in main agronomic characteristics was investigated. The "Rolling leaf" mutation was analyzed to search for the kind of Tos and difference of copy number in rice, and the retrotransposon present in Tos family.

\section{Materials and Methods}

\subsection{Plant Materials Growing Conditions}

Calli of the japonica variety, 'Ilpum' of Oryza sativa were induced in germinated dehulled seeds on a Murashige-Skoog solid medium [19] containing 2,4-20 dichlorophenoxyacetic acid at $2 \mathrm{mg} \cdot \mathrm{L}^{-1}$, casein hydrolysate $\left(2 \mathrm{~g} \cdot \mathrm{L}^{-1}\right)$, sucrose $\left(30 \mathrm{~g} \cdot \mathrm{L}^{-1}\right), 21$ and gelrite $\left(5 \mathrm{~g} \cdot \mathrm{L}^{-1}\right)$. De-hulled seeds were incubated for 4 weeks at $26 \pm 1{ }^{\circ} \mathrm{C}$ in permanent darkness. After incubation for 4 weeks, calli on the selection medium with somatic embryo-like structures were transferred to MS medium supplemented with $30 \mathrm{~g} \cdot \mathrm{L}^{-1}$ sucrose, $1 \mathrm{mg} \cdot \mathrm{L}^{-1} 1$-naphthaleneacetic acid, $5 \mathrm{mg} \cdot \mathrm{L}^{-1}$ kinetin, and $5 \mathrm{~g} \cdot \mathrm{L}^{-1}$ gelrite and exposed to intense light (approx. $45-5 \mathrm{mEm}^{-2} \mathrm{~s}^{-1}$ ) at $26 \pm 1^{\circ} \mathrm{C}$. After 3 weeks, the regenerated shoots were transferred to a bottle $(6 \times 16 \mathrm{~cm})$ containing a fresh medium. When the shoots reached the top of the box, the plantlets were transferred to soil.

\subsection{Measurement of Agronomic Traits}

Progeny populations $\left(\mathrm{S}_{1}, \mathrm{~S}_{2}\right)$ grown from the regenerated seed-culture $\left(\mathrm{S}_{0}\right)$ were planted 8 at $30 \times 15 \mathrm{~cm}$ planting distance on the practice field in Kyungpook National University, and the main agronomic characters were investigated. Brown rice's protein local, and starch content were analyzed by NIRS (Near-Infrared Spectroscopy, Foss 6500), and the amylose content used 3 repeated mean values provided by colorimetry of Juliano et al. [9].

\subsection{Genomic DNA Extraction, PCR, Southern, and RT-PCR Analysis}

DNA from the mutants was extracted using the CTAB method [20-25]. Ten-microgram aliquots of DNA were first digested with Hae III and then electrophoresed onto a $0.8 \% 18$ agarose gel. PCR was performed in $50 \mu \varrho$ volume of [1.5 mM $\mathrm{MgCl}_{2}$, Taq DNA polymerase, and a corresponding buffer from GibCo (Invitrogen, Carlsbad, Calif., http://www.invitrogen.com). Primer made amino acid sequences [8] of Tos $4 \sim$ Tos 20 by DNAsis 3.0 Programs (Hitachi, Japan) using GenBank's data base confirmed the relationship existence of retrotransposon elements of 'Ilpum' (Table 1). The DNA was denatured at $93^{\circ} \mathrm{C}$ for 5 min followed by 35 cycles of amplification (1 $\min$ at $93^{\circ} \mathrm{C} ; 2 \mathrm{~min}$ at $40^{\circ} \mathrm{C} ; 2 \mathrm{~min}$ at $72^{\circ} \mathrm{C}$ ); the final incubation at $72^{\circ} \mathrm{C}$ was extended to $5 \mathrm{~min}$, and the reaction was cooled and kept at $4^{\circ} \mathrm{C}$. PCR were performed in a PTC-200 thermal cycler (MJ Research). RT-PCR (reverse transcriptase-PCR) was used to analyze the mutants containing the retrotransposon elements as determined by the PCR and Southern analysis [2]. The total RNAs that were from the putative rice plants (leaves) using guanidine thiocyanate were isolated [11].

\subsection{Histology and Microscopy Observation}

Fresh hand-cut sections ( $20 \mathrm{~mm}$ ) of rice leaf were fixed in FAA solution [(10 $\mathrm{ml}$ Formalin, $5 \mathrm{ml}$ Acetic acid (glacial), $\left.\left.95 \mathrm{ml} \mathrm{50 \%} \mathrm{Ethylalcohol),} \mathrm{(16} \mathrm{to} 48 \mathrm{~h}, 48^{\circ} \mathrm{C}\right)\right]$ and dehydrated through a graded ethanol series. Treated samples were transferred into water. The sections were microscopically examined (Automatic plant microtome, Mt-3, NK system) and photographed. The samples were embedded in paraffin (Fluka) and polymerized at 56 $58^{\circ} \mathrm{C}$. Sections $(50 \mu \mathrm{m})$ were cut and dropped with filtered paraffin, microscopically examined (Olympus, BX50), and photographed. Area measurements of the vascular elements were performed using an Olympus analySIS TS Lite software.

\subsection{Amplification of Sequences Flanking Transposed Tos 17}

Sequences flanking the transposed Tos 17 (target-site sequences) were amplified by an adaptor-PCR. Targetsite sequences were amplified using the rice total DNA, respectively, as described [24] except that the total DNA was digested with Hae III. Two sets of primers were used for the two-step PCR: adaptor primer-1, GCGTAATACGACTCACTATAGCAATTAACC and Tos 17 primer-1, TGCTCTCCACTATGTGCCCTCCGAGCTA were used for the first PCR; the adaptor primer-2, GACTCACTATAGCAATTAAC and Tos 17 primer-2, ACAAGTCGCTGATTTCTTCAC were used for the second reaction. PCR was performed in a PTC-200 thermal cycler (MJ Research) and conducted as follows: first, the denaturetion step at $95^{\circ} \mathrm{C}$ for 5 minutes, 20 cycles of 30 seconds at $94^{\circ} \mathrm{C}$ and 1 minutes at $72^{\circ} \mathrm{C}$, followed by a final elongation step at $72^{\circ} \mathrm{C}$ for 10 minutes; second the PCR was conducted with $5 \mathrm{ul}$ of the first PCR product under the following conditions: denaturation step at $94^{\circ} \mathrm{C}$ for $5 \mathrm{~min}$, 
Table 1. The primer sequence of Tos families for PCR.

\begin{tabular}{|c|c|c|}
\hline \multirow{2}{*}{ Tos families } & \multicolumn{2}{|c|}{ Primer sequence } \\
\hline & Forward $\left(5^{\prime} \rightarrow 3^{\prime}\right)$ & Reverse $\left(3^{\prime} \rightarrow 5^{\prime}\right)$ \\
\hline Tos 4 & ACATTTTTACATggAgAgCTTgAg & ATTCTACATCCTCATCagTAC \\
\hline Tos 5 & ATATgCATCTCCTgATgCAgACTA & CAAgCACAAAATAACTCССТC \\
\hline Tos 6 & gCACACTATgATTTAgAgTTgCAT & AgTgTTCCTgTCCTggATTgC \\
\hline $\operatorname{Tos} 7$ & gACAgATATAAAgCTAgATTggTT & AgTTTCTCAgTTggTgACAgA \\
\hline Tos 8 & gCTATgTTACAAgCgAggACATAC & CTTTTgCAACTAAgCgAgCTT \\
\hline Tos 9 & gCTTACTCAgCTTCgCAAgCTCgA & AgTCTTgCCTTgTgCCTAATT \\
\hline Tos 10 & gCAAAATCCTAATggAAAggTggA & AgTTATgTCAggTCgTgTAtg \\
\hline Tos 11 & gCTAgTAgTgATgTCAgTCTACTg & gTTgTgAgTgTACATTACTgC \\
\hline Tos 12 & gCATTTTTACATggggAgTTAggA & gAAgATAATCTgAAATgTgCA \\
\hline Tos 13 & gCgTTTTTgCATggAgAgCTTgAg & ACTgAgCAgCTgACAACTTAA \\
\hline Tos 14 & TACATTgTATACCTCgTggATgAC & TAAgCACAAgATCACCCCTTC \\
\hline Tos 15 & gACggTACTATTgAAAAgTACAag & AgTTgATTCCTAgCAATTCTC \\
\hline Tos 16 & CTCAACCTCATAATggACgTgATA & CATggTTTgTATCTCATgAgC \\
\hline Tos 17 & gCTTTTCTTCATggTgATCTTCAT & gAgTAACAACAAAgTAcgACC \\
\hline Tos 18 & gCATTTTTACATggggAgTTAgAA & AgTCAggACgAgAACATACCA \\
\hline Tos 19 & gTTACTTCTTgggAATTgAggTTT & ggATCATTAgCAATCTgTAtg \\
\hline Tos 20 & ACAgTTTgCCCTCAgAACATgTTC & AgTCTTCACATCTAACTgCTC \\
\hline
\end{tabular}

40 cycles of 30 seconds at $94^{\circ} \mathrm{C}, 30$ seconds at $60^{\circ} \mathrm{C}$, and 1 minute at $72^{\circ} \mathrm{C}$, followed by a final elongation step at $72^{\circ} \mathrm{C}$ for $10 \mathrm{~min}$. Amplified products were loaded on a $1 \%$ agarose gel. The PCR products were purified by HiYield $^{\mathrm{TM}} \mathrm{Gel} / \mathrm{PCR}$ DNA Extraction Kit (RBC) and sequenced by ABI3730XL (using Tos 17 primer-2).

\subsection{Sequence Analysis and Database Search}

Handling of primary sequences and multiple sequence alignment were carried out using the DNAsis 3.0 software (Hitachi, Japan). Computer-based amino acid similarity searches of the Protein Identification Research, Genome annotation DB (Gramene, http://www.gramene. org/) and NCBI (http://www.ncbi.nlm.nih.gov/) were carried out with the FST (Flanking Sequence Tag).

\section{Results}

There were 4 lines (1.3\%) among the entire 297 lines that showed evidence of "rolling 19 leaf" mutant that occurred at the progeny $\left(\mathrm{S}_{1}\right)$ using the brown rice culture of japonica type 'Ilpum'. Compared with the "rolling leaf" mutant mutant, the donor plant 'Ilpum', showed normal leaf with equal small veins, protoplasm formations, and conductive tissue of right and left in the midrib (Figure 1). The mutant had no equal arrangement of midrib and small veins. Because the bulliform cell was well-developed, it ranged extensively, and the conductive tissue of the midrib was thick. Also, the sclerenchyma was thin (Figures 1(c) \& (d)).

Though the mutant "rolling leaf" plant high and the panicle number was less than the donor plant (Table 2), it was believed that the growth change with morphological characteristicsof leaf was secondary. These agronomic characteristics should be studied further to understand deeply the mechanism of such leaves.

The retrotransposon's activation known as one of the main causes of the conversion that occurred in tissue culture of rice, specifically for the 17 set oligonucleotide primers from conserved domain of Tos $4 \sim 20$ reported in the 'Nipponbare' were analyzed 13 (Table 1). The PCR that the primers used for 3 classes (Tos 12, 15, 17) of the Tos 14 element was amplified in the 'Ilpum' of the mutants (Figure 2(a)). Tos element's that appeared in the 'Ilpum' were different from the 'Nipponbare' [8]. These differences were believed to be from a genotype difference caused by the cultivar which was used in PCR am- 
(a)

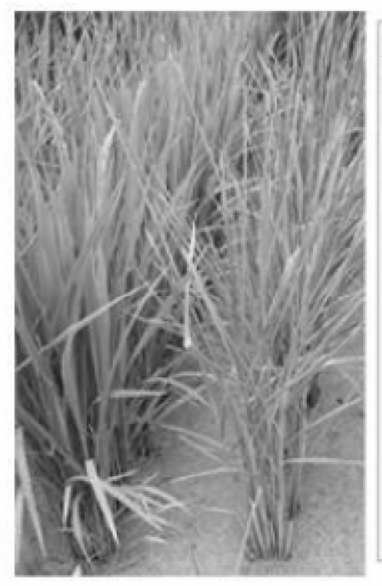

Ilpum (b)

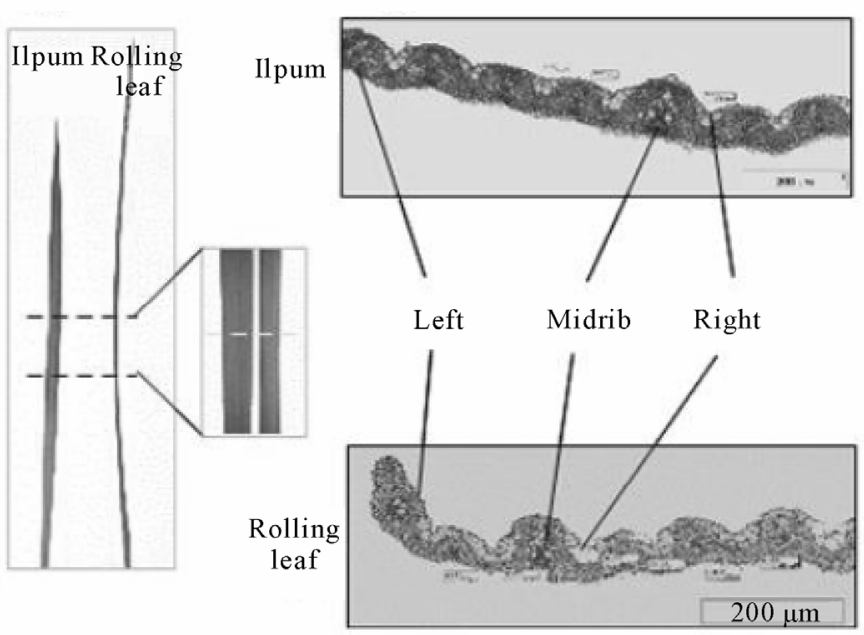

(d)
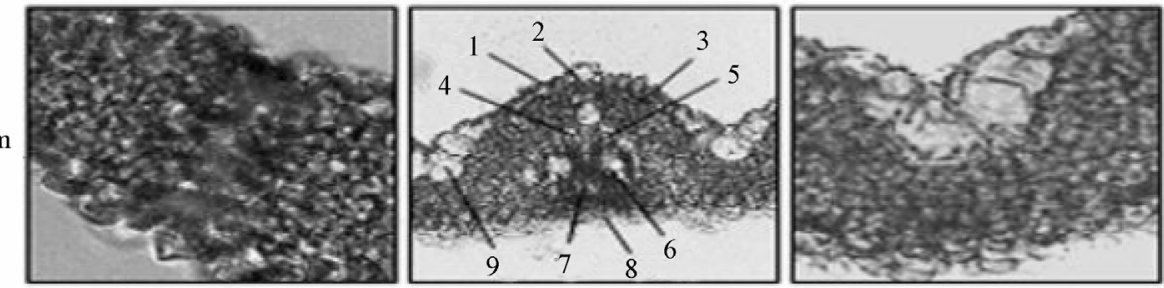

Left

Midrib

Right
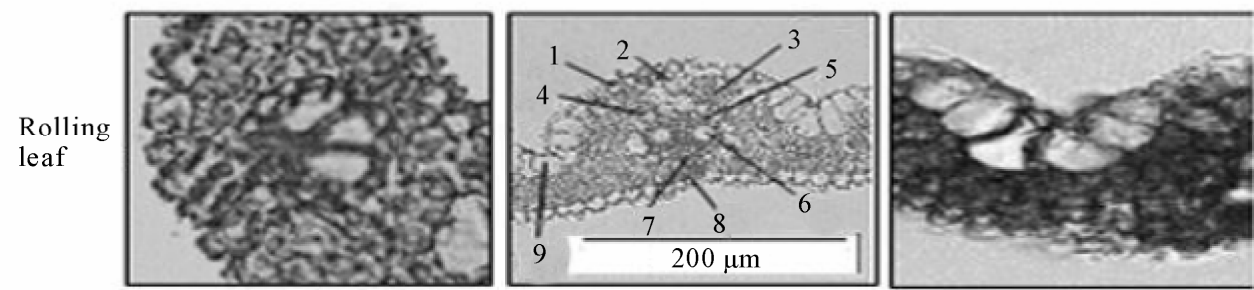

Figure 1. Histological differences between, 'Ilpum' and a mutant with rolling leaf. A: Agronomic traits of the mutants with rolling leaves. B: Young leaf of, 'Ilpum' and the mutant. C: The defective sclerenchymatous cells on the abaxial side of, 'Ilpum' and the mutant. D: Organization of megascopic leaf. 1: upper epidermis, 2: adaxial sclerenchyma, 3: mesophyll cells, 4: vascular bundle sheath, 5: mestome sheath, 6: 11 xylem, 7: phloem, 8: lower epidermis, 9: bulliform cell.

plification. The studied activation and copy numbers confirmed that Tos elements were present in 'Ilpum' (Figure 2(b) and (c)). There were Tos 12 and Tos 15 in 19 positions such as the donor plant, and Tos 17 was observed in 2 polymorphic bands in \#15, \#16 mutants, "rolling leaf", respectively. These results could confirm in the Southern analysis by the Tos 17 probe, and was activated in the $\mathrm{S}_{2}$ progeny using the RT-PCR.

Interrelation analysis of the "rolling leaf" mutant and Tos 17 activations achieved the FST (Flanking Sequence Tag) analysis in the Genome annotation DB (Gramene, http://www.gramene.org/; NCBI, http://www.ncbi.nlm.nih. gov/) using a construed 1 sequence (Tables 3 and 4). Tos 17 was situated in chromosome 11 and 12 in the donor 2 plant, 'Ilpum' (Table 3 and Figure 3).

The homology gene had about 12 kinds in the area that Tos 17 had been inserted into 1 (Table 4). They were

Table 2. Agronomic traits of the mutants with rolling leaves.

\begin{tabular}{ccccc}
\hline Lines & $\begin{array}{c}\text { No. of } \\
\text { lines }\end{array}$ & $\begin{array}{c}\text { Culm length } \\
(\mathrm{cm})\end{array}$ & $\begin{array}{c}\text { Panicle length } \\
(\mathrm{cm})\end{array}$ & $\begin{array}{c}\text { No. of } \\
\text { tillers }\end{array}$ \\
\hline Rolling leaf & 4 & $81.3 \pm 6.8$ & $21.5 \pm 2.4$ & $5.9 \pm 1.1$ \\
Ilpum(Ck) & - & $72.0 \pm 4.2$ & $21.1 \pm 1.2$ & $14.5 \pm 2.4$ \\
\hline
\end{tabular}


(a)

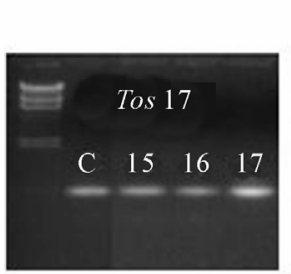

(c)
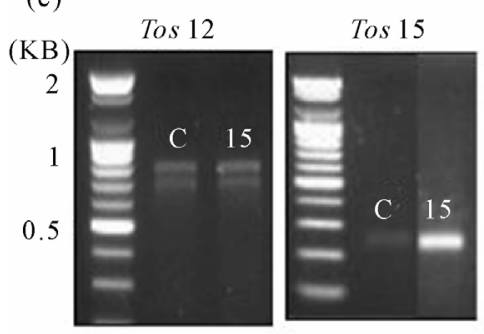

(b)

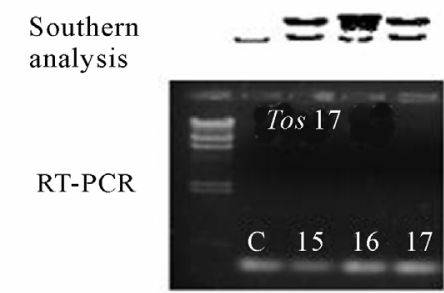

$\operatorname{Tos} 17$

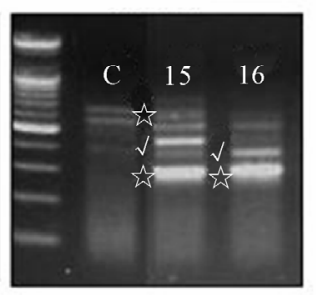

Figure 2. Detection of retrotransposon elements in the mutants and a donor cultivar 'Ilpum' using genomic DNA analysis. A: Detection of retrotransposon Tos 17 primer by PCR. m; size marker ( $\lambda$ /HindIII). c; 'Ilpum'. \#15 \#17; mutants. B: DNA gel blot analysis by $S_{1}$ progeny and RT-PCR by $S_{2}$ progeny of the mutants, 'rolling leaf'. $C$ : The second PCR products derived from PCR amplification between the first PCR products and adaptor primer-1 in somaclonal mutants and a donor cultivar 'Ilpum'. v; The bands were isolated from agarose gel, and sequenced (pass). is ; The bands were isolated from agarose gel, and sequenced (fail). c; Ilpum, \#15 16; mutants of rolling leaf.

arabinoxylan arabinofuranohydrolase isoenzyme AXAHII, cytochrome cd1-nitrite reductase-like, RNA-binding

region RNP-1, metallothionein-like protein 1, and Cytochrome P450. Also, transcription factor rough sheath 2 like proteins were analyzed and showed high interrelationship in morphogenesis of "rolling leaf".

\section{Discussions}

The mutant "rolling leaf $(\mathrm{rl})$ " was reported in 11 different kinds of the transposon element which affected the rolling leaf until the present. Also the rl1 rl6 alelle, recessive gene of 6 kinds, were situated within each chromosome 1, 4, 12, 3, 7 thru formal marker analysis [12,13]. The $r l 7 \sim r l 10$ alelle mapping in the chromosome $5[16,17$, $21,26,27], \mathrm{Rl}(t)$, had an incomplete recessive gene, mapping between the long arms (137 kb area) of chromosome 2 [22]. Yet there was also no report that there was any direct gene cloning. OsAGO7, the "rolling leaf" related gene, was reported to have an upward leaf curling in the overexpressing transformants [23]. Zhang et al. [28] reported that the Shallot-like 1 (SLL 1), MYB transcription control factor, belonging to the KANADI family was caused by the leaf-rolling cause on the chromosome 9 in the rice. The plant height of the mutant "rolling leaf" was higher than the donor plant. It was reported that there was a photosynthesis difference because of the carbon fixing or the gas exchange according to the three-dimensional structure of leaf [5]. Though the mutant "rolling leaf" was the transposon of the Tos 17, it occurred in chromosome 11 and 12, each differed from the studies of Shi et al. [23] and Zhang et al. [28] and the findings in this research (Table 3 and Figure 3). This result maybe

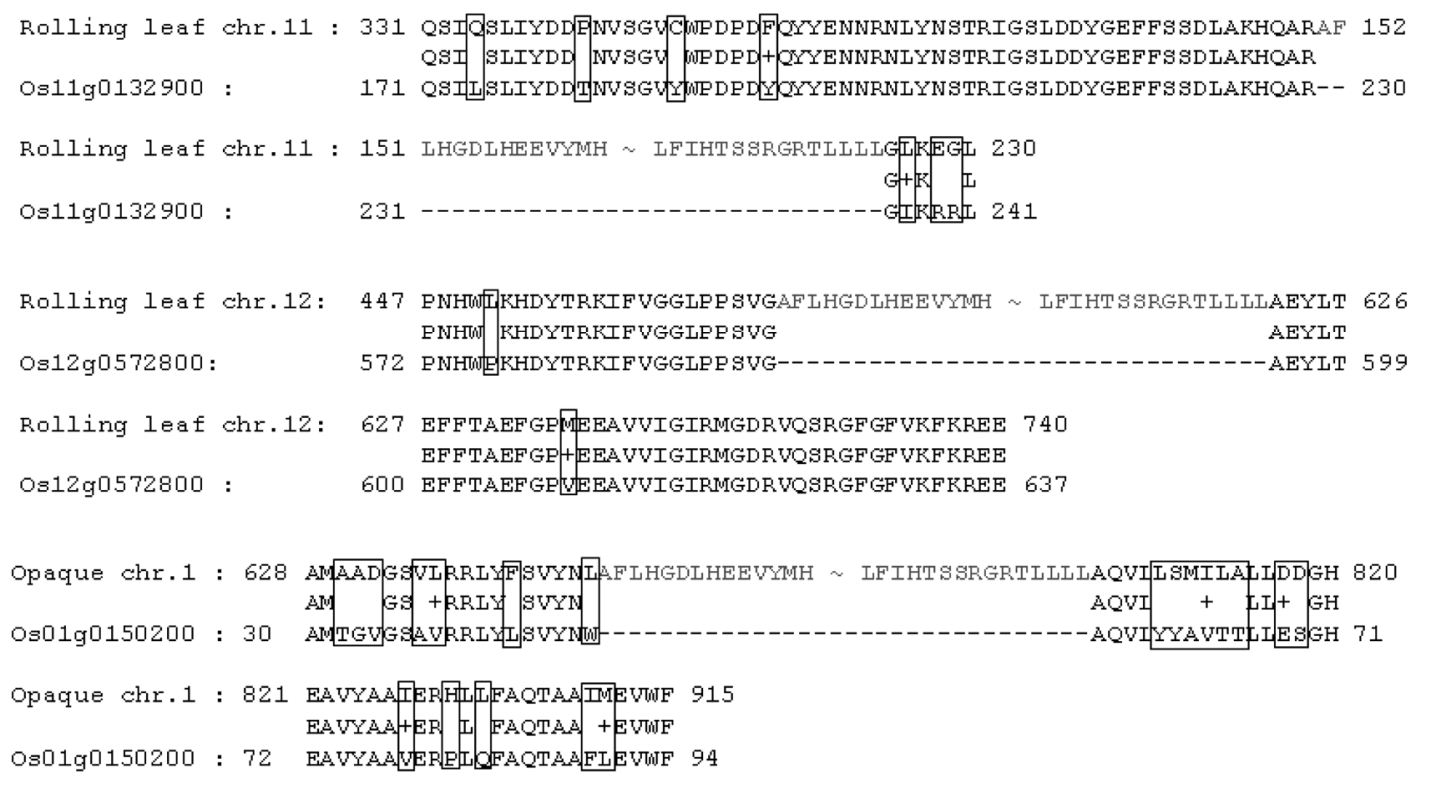

Figure 3. Genes disrupted by insertion of Tos 17. Amino acid sequences deduced from target-site sequence (rolling leaf) are aligned with sequenced of GenBank data ('Nipponbare'). Red letters: amino acid sequence of Tos 17, Rectangles: no homology. 
Table 3. Chromosome locations of Tos 17 in a rice mutant with rolling leaf.

\begin{tabular}{|c|c|c|c|c|c|c|c|c|}
\hline \multicolumn{2}{|c|}{$\begin{array}{l}\text { Sequenced flanking } \\
\text { region of Tos-DNA }\end{array}$} & \multicolumn{4}{|c|}{ Matched region with rice chromosomes } & \multirow{2}{*}{$\begin{array}{l}\text { Tos- DNA end } \\
\text { Tos- DNA end }\end{array}$} & \multirow{2}{*}{$\begin{array}{l}\text { Adaptor start } \\
\text { Adaptor start }\end{array}$} & \multirow{2}{*}{$\begin{array}{l}\text { Reading length } \\
\text { Reading length }\end{array}$} \\
\hline from & to & length & Chr. & from & to & & & \\
\hline 195 & 306 & 112 & 11 & 1492553 & 1492664 & 194 & 307 & 340 \\
\hline 195 & 372 & 178 & 12 & 23812926 & 23812749 & 194 & 373 & 406 \\
\hline
\end{tabular}

Table 4. Annotated genes of Tos 17 inserted flanking regions on chromosome in a rice 4 mutant with "rolling leaf".

\begin{tabular}{|c|c|c|c|}
\hline Chromosome No. & Accession No. & Protein & Origin \\
\hline \multirow{6}{*}{11} & NM_001072196.1 & Arabinoxylan arabinofuranohydrolase isoenzyme AXAH-II & Oryza sativa L. \\
\hline & NM_001072197.1 & Cytochrome cd1-nitrite reductase-like & Oryza sativa L. \\
\hline & NM_001072198.1 & Protein kinase family protein & Oryza sativa L. \\
\hline & NM_001072200.1 & TPR-like domain containing protein & Oryza sativa $\mathrm{L}$. \\
\hline & NM_001072201.1 & Resistance protein candidate (Fragment) & Oryza sativa $L$. \\
\hline & NM_001072202.1 & RNA-binding region RNP-1 & Oryza sativa L. \\
\hline \multirow{6}{*}{12} & FAA00315.1 & TPA: metallothionein-like protein & Oryza sativa L. \\
\hline & ABR25982.1 & Metallothionein-like protein 1 & Oryza sativa L. \\
\hline & ABR25363.1 & Mitochondrial import inner membrane translocase subunit tim9 & Oryza sativa $\mathrm{L}$. \\
\hline & BAB61618.1 & Transcription factor rough sheath 2 like protein & Oryza sativa L. \\
\hline & BAC78592.1 & pre-mRNA splicing factor & Oryza sativa L. \\
\hline & AAY44413.1 & Cytochrome P450 & Oryza sativa $\mathrm{L}$. \\
\hline
\end{tabular}

brought about by the mixing of a lot of gene numbers that caused the "rolling leaf" mutant. The FST analysis of the mutant "rolling leaf" and the cause of the mutation should be studied continuously via genetic and molecular breeding of the S3 progeny to determine the relation of gene function.

\section{Acknowledgements}

We are grateful to Dr. Baek Hie Nahm (bhnahm@ gmail.com) for the technological study and critical reading of the manuscript. Sylvia T. Lapitan (stlapitan@yahoo. com) for critical proofreading of the manuX-X-SCRIPT. Flanking DNA sequencing was supported by GreenGene Biotech Inc. This work was supported by a grant from the Next Biogreen 21 R\&D program, Rural Development Administration, Republic of Korea.

\section{REFERENCES}

[1] K. Arjun, E. Guiderdoni, G. An, Y. C. Hsing, C. D. Han, M. C. Lee, S. M. Yu, N. Upadhyaya, S. Ramachandran and Q. Zhang, "Mutant Resources in Rice for Functional Genomics of the Grasses," Plant physiology, Vol. 149, No. 1, 2009, pp. 165-170. doi:10.1104/pp.108.128918
[2] H. G. Chin, M. S. Choe, S. H. Lee, S. H. Park, S. H. Park, J. C. Koo, N. Y. Kim, J. J. Lee, B. G. Oh, G. Yi, S. C. Kim, H. C. Choi, M. J. Cho, C. D. Han, "Molecular Analysis of Rice Plants Harboring an Ac/Ds Transposable Elementmediated Gene Trapping System," The Plant Journal, Vol. 19, No. 5, 1999, pp. 615-623.

[3] L. Gao, E. M. McCarthy, E. W. Ganko and J. F. McDonald, "Evolutionary History of Oryza sativa LTR RetroTransposons: A Preliminary Survey of the Rice Genome Sequences," BMC Genomics, Vol. 5, No. 1, 2004, pp. 1-18. doi:10.1186/1471-2164-5-18

[4] G. Gavazzi, C. Tonelli, G. Todesco, E. arreghini, F. Raffaldi, F. Vecchio, G. Barbuzzi, M. Biasini and F. Sala, "Somaclonal Variation Versus Chemically Induced MutaGenesis in Tomato(Lycopersicon esculentum L.)," Theoretical and Appled Genetics, Vol. 74, No. 6, 1987, pp. 733-738.

[5] Y. M. Govaerts, S. Jacquemoud, M. M. Verstraete and S. L. Ustin, "Three-10 Dimensional Radiation Transfer Modeling in a Dicotyledon Leaf," Applied Optics, Vol. 35, No. 33, 1996, pp. 6585-6598. doi:10.1364/AO.35.006585

[6] H. Hirochika, A. Fukuchi and F. Kikuchi, "Retrotransposon Families in Rice," Molecular and General Genetics, Vol. 233, No. 1-2, 1992, pp. 209-216. doi:10.1007/BF00587581 
[7] H. Hirochika, H. Otsuki, M. Yoshikawa, Y. Otsuki, K. Sugimoto and S. Takeda, "Autonomous Transposition of the Tobacco Retrotransposon Tto 1 in rice," The Plant Cell, Vol. 8, No. 4, 1996a, pp. 725-734.

[8] H. Hirochika, K. Sugimoto, Y. Otski, H. Tsugawa and M .Kanda, "Retrotransposones of Rice Involved in Mutations Induced by Tissue Culture," Proceedings of $\mathrm{Na}$ tional Acadenny of Sciences of the United States of America, Vol. 93, No. 15, 1996b, pp. 7783-7788. doi:10.1073/pnas.93.15.7783

[9] B. O. Juliano, C. M. Perez, A. B. Blakeney, T. Castillo, N. Ongseree, B. Laignelet, E. T. Lapis, V. V. S. Murty, C. M. Paule and B. D. Webb, "International Cooperative Testing on the Amylose Content of Milled Rice," Starch, Vol. 33, No. 5, 1981, pp. 157-162.

[10] Y. U. Jun, S. Hu, J. Wang, S. Li, K. S. G. Wong, B. Liu, Y. Deng, L. Dai, Y. Zhou, X. Zhang, M. Cao, J. Liu, J. Sun, J. Tang, Y. Chen, X. Huang, W. Lin, C. Ye, W. Tong, L. Cong, J. Geng, Y. Han, L. Li, W. Li, G. Hu, X. Huang, W. Wi, J. Li, Z. Liu, L. Li, J. Liu, Q . Qi, J. Liu, L. Li, X .Wang, H. Lu, T. Wu, M. Zhu, P. Ni, W. Dong, X. Ren, X. Feng, P. Cui, X. Li, H. Wang, X. Xu, W. Zhai, Z. Xu, J. Zhang, S .He, J. Zhang, J. Xu, K. Zhang, X. Zheng, J. Dong, W. Zeng, L. Tao, X. Chen, J. He, D. Liu, W. Tian, H .Xia, G. Li, H. Gao, P. Li, W. Chen, X. Wang, Y. Zhang, J. Hu, J. Wang, S. Liu, J. Yang, G. Zhang, Z. Li, C. Zhou, R. Chen, B. Hao, W. Zheng, S. Chen, W. Guo, G. Li, S. Liu, G. Hunag, M. Tao, J. Wang, L. Zhu, L. Yuan and H. Yang, "A Draft Sequence of the Rice (Oryza sativa ssp. indica) Genome," Chinese Science Bulletin, Vol. 46, No. 23, 2001, pp. 1937-1942. doi:10.1007/BF02901901

[11] M. Kawai, S. Kidou, A. Kato, H. Uchimiya, "Molecular Characterization of cDNA Encoding for Adenylate Kinase of Rice (Oryza sativa L.)," The Plant Journal, Vol. 2, No. 6, 1992, pp. 845-854.

[12] G. S. Khush and T. Kinoshita, "Rice Karyotype, Marker Genes, and Linkage Group," Rice Biotechnology, CAB International, Wallingford, 1991, pp. 83-107.

[13] T. Kinoshita, "Gene Analysis and Linkage Map," Biology of Rice, JSSP/Elsevier, Tokyo, 1984 pp. 187-274.

[14] P. J. Larkin, P. M. Bank, R. Bhati, R. I. S. Brettelli, P. A. Davies, S. A. Ryan, W. R. Scowcroft, L. H. Spindle and G. T. Tanner, "From Somatic Variant to Variant Plants: Mechanisms and Applications," Genomes, Vol. 31, No. 2, 1989, pp. 705-711.

[15] P. J. Larkin and W. R. Scowcroft, "Somaclonal Variation-A Novel Source of Variability from Cell Cultures for Plant Improvement," Theoretical and Applied Genetics, Vol. 60, No. 4, 1981, pp. 197-214. doi:10.1007/BF02342540

[16] S. G. Li, Y. Q. Ma, P. He, H. Y. Li, Y. Chen, K. D. Zhou and L. H. Zhu, "Genetics Analysis and Mapping the Flag Leaf Roll in Rice (Oryza. sativa. L.)," Journal Sichuan Ag-riculture University, Vol. 16, 1998, pp. 391-393.

[17] Z. Luo, Z. Yang, B. Zhong, Y. Li, R. Xie, F. Zhao, Y. Ling and G. He, "Genetic Analysis and Fine Mapping of a Dynamic Rolled Leaf Gene, RL 10(t), in Rice (Oryza. sativa. L.)," Genome, Vol. 50, No. 9, 2007, pp. 811-817. doi:10.1139/G07-064

[18] A. Miyao, Y. Iwasaki, H. Kitano, J. I. Itoh, M. Maekawa, K. Murata, O. Yatou, Y. Nagato and H. Hirochika, "A Large-Scale Collection of Phenotypic Data Describing an Insertional Mutant Population to Facilitate Functional Analysis of Rice Genes," Plant Molecular Biology, Vol. 63, No. 5, 2007, pp. 625-635. doi:10.1007/s11103-006-9118-7

[19] T. Murashige and F. Skoog, "A revised Medium for Rapid Growth and Bioassays with Tobacco Tissue Cultures," Physioogial Plantarum, Vol. 15, No. 3, 16 1962, pp. 473-497.

[20] K. M. Nori, K. Miyoshi, K. I. Nonomura, Y. Yamazaki and Y. Ito, "Rice Mutants and Genes Related to Organ Development, Morphogenesis and Physiological Traits," Plant Cell Physiology, Vol. 46, No. 1, 2005, pp. 48-62. doi:10.1093/pcp/pci506

[21] Y. j. Shao, Z. X. Chen, Y. F. Zhang, E. H. Chen, D. C. Qi, J. Miao and X. B. Pan, "One Major QTL Mapping and Physical Map Construction for Rolled Leaf in Rice," Acta Genetica Sinica (in Chinese), Vol. 32, No. 5, 2005a, pp. 501-506.

[22] Y. J. Shao, C. H. Pan, Z. X. Chen, S. M. Zuo, Y. F. Zhang and X. B. Pan, "Fine Mapping of an Incomplete Recessive Gene for Leaf Rolling in Rice(Oryza. sativa. L.)," Chiness Science Bulletin (in Chinese), Vol. 50, No. 21, 2005b, pp. 2466-2472.

[23] Z. Y. Shi, J. Wang, X. S. Wan, G. Z. Shen, X. Q. Wang and J. 1. Zhang, "Over-Expression of Rice OsAGO 7 Gene Induces Upward Curling of the Leaf Blade that Enhanced Erect-Leaf Habit," Planta, Vol. 226, No. 1, 2007, pp. 99-108. doi:10.1007/s00425-006-0472-0

[24] K. Sugimoto, Y. Otsuki, S. Saji and H. Hirochika, "Transposition of the Maize Ds Element from a Viral Vector to the Rice Genome," The Plant Journal, Vol. 5, No. 6, 1994, pp. 863-871. doi:10.1046/j.1365-313X.1994.5060863.x

[25] B. Winnepenninckx, T. Backeljau and R. De Wachter, "Extraction of high molecular weight DNA from mollusks," Trends in Genetics, Vol. 9, No. 12, 1993, pp. 407. doi:10.1016/0168-9525(93)90102-N

[26] Q. J. Xie, M. C. Ruch and J. H. Oard, "Homozygous Variation in Rice Somaclones: Non Random Variation Instead of Mitotic Recombination," Crop Science, Vol. 35, No. 4, 1995, pp. 954-957. doi:10.2135/cropsci1995.0011183X003500040002x

[27] C. J. Yan, S. Yan, Z. Q. Zhang, G. H. Liang, J. F. Lu and M. H. Gu, "Genetic Analysis and Gene Fine Mapping for a Rice Novel Mutant $r$ 9(t) with Rolling Leaf Character," Chi- ness Science Bulletin (in Chinese), Vol. 51, No. 1, 2006, pp. 63-69.

[28] G. H. Zhang, Q. Xu, X. D. Zhu, Q. Qian and H. W. Xue, "Shallot-Like is a KANDI Transcription Factor that Modulates Rice Leaf Rolling by Regulating Leaf Abaxial Cell Development," The Plant Cell Preview, Vol. 21, No. 3, 2009, pp. 719-735. doi:10.1105/tpc.108.061457 